
\title{
Research S Surate \\ Laboratory Studies on The Effect of MSW Leachate on Soil by Using One-Dimensional Soil Column Method
}

R Rajapriya ( $\sim$ rajapriyajayan2011@gmail.com )

Pondicherry Engineering College

\section{Murugaiyan}

Pondicherry Engineering College

\section{Research}

Keywords: Leachate, Municipal solid waste, One-Dimensional soil column, Soil characteristics

Posted Date: June 8th, 2021

DOl: https://doi.org/10.21203/rs.3.rs-494287/v1

License: (c) (1) This work is licensed under a Creative Commons Attribution 4.0 International License.

Read Full License 


\section{Abstract}

To understand the soil-pollutant interaction geo-environmental engineer design a hydraulic barrier to control the transport of pollutant through the soil and minimize the pollution of affecting the soil properties. Hence, in this study one-dimensional soil column method was stimulated similar to the field conditions. The extraction of leachate from the municipal solid waste was manipulated based on the annual precipitation data. The test result showed that the concentration of extracted leachate was increased up to 45 days and slightly decreased by increasing the addition of water. The interaction of extracted leachate changes the soil characteristics (i.e., increasing tendency by period). The result showed that the LL and PL of the soil was increased by increasing the addition of leachate. The UCS was increased from $167.80 \mathrm{kPa}$ to $176.54 \mathrm{kPa}$ up to 75 th days and then decreased gradually at 95th to 105th days. Conversely, hydraulic conductivity was decreased at the initial stage and then gradually increased at the end of the experiment. These changes in the soil characteristics are mainly due to the alters of soil particles into dispersive structure with more effective pore space, which reduces the soil strength and increases the permeability value.

\section{Introduction}

Due to fast population development and industrialization, large quantities of waste have been produced in the last year and these wastes is simply disposed of in the landfill without proper precaution. When the rainwater enters into the municipal solid waste it undergoes the decomposition process and leaches out the highly contaminated liquid, which pollutes the soil properties and ground water system $(1,2)$. To understand the soil-pollutant interaction is important for the geo-environmental engineer to design a hydraulic barrier to control the migration of pollutant through the soil and changing the soil properties. Extensive literature has been available on the groundwater pollution due to the effect of MSW leachate (3, 4). However, little effort was made to determine the impact of MSW leachate on soil properties. In addition, most researchers have used various types of chemical to understand the geotechnical behavior of soil pollutant interaction. But there was no attempt to simulate the contamination scheme close to the situation of the field, because the condition of the field is considerably different from the conditions controlled. To achieve this goal, in this module one-dimensional soil-column method has been used to simulate the field conditions in the laboratory studies over a long-term period. For this purpose, the leachate has been extracted from the municipal solid waste similar to the field condition by calculating the annual precipitation data. The extracted leachate has been passed into the soil column to determine the changes in the geotechnical behavior of soil.

\section{Materials And Methodology}

To determine the soil-pollutant interaction, the available leachate is not sufficient to perform the laboratory experiment. The municipal solid waste was therefore collected from the dumping sites in order to prepare the leachate, and uncontaminated natural soil is also collected in an airtight polythene bag. 


\subsection{Municipal Solid Waste}

The collected MSW was carried to the laboratory and placed under ordinary laboratory temperature in the air-tight container until it was actually used. Municipal solid waste involves all kinds of waste such as cooking, paper, cardboard, clothing, plastic and glassware etc.

\subsection{Natural clay soil}

The uncontaminated natural soil was collected from the dumping site and stored until its real use in the air-tight polythene bag. Air is dried and crushed into the wooden mallet before undertaking the laboratory testing of the soil sample and then testing was performed as per IS 2720. The geotechnical properties of soil sample as shown in Table 1.

Table 1

Geotechnical characteristics of Natural soil

\begin{tabular}{|lll|}
\hline Sl.no & Parameters & Values \\
\hline 1 & Clay content (\%) & 38.50 \\
2 & Silt Content (\%) & 61.50 \\
3 & Liquid Limit (LL) (\%) & 58.00 \\
\hline 4 & Plastic Limit (PL) (\%) & 28.66 \\
\hline 5 & Plasticity Index (\%) & 29.34 \\
\hline 7 & Shrinkage Limit (\%) & 11.52 \\
\hline 8 & Max. dry density (g/cc) & 1.77 \\
\hline 9 & Unconfined compressive strength (UCS) (kPa) & 17.05 \\
\hline 10 & Hydraulic conductivity (cm/s) & $8.63 \times 10^{-5}$ \\
\hline
\end{tabular}

\subsection{Methodology}

Laboratory studies were conducted using two experiment set-ups to determine the impact of soilpollutant interaction;

First experiment set-up: Extraction of leachate from municipal solid waste

Second experiment set-up: One-Dimensional soil column method has been used to determine the effect of soil on the municipal solid waste leachate.

\subsubsection{Leachate preparation experimental set-up}


The extraction of leachate was done by taking five barrels with $68 \mathrm{~cm}$ height and $35 \mathrm{~cm}$ diameter. In the bottom of each container a metal wire mesh has been provided. Above the wire mesh $10 \mathrm{~cm}$ thickness gravel layer was placed to prevent the blocking of the waste which enabled to flow the leachate continuously. The weight of the MSW filled in each barrel has been calculated depending on the real density of the municipal solid waste, which is approximately $700 \mathrm{~kg} / \mathrm{m}^{3}$ in the container (without compaction) and $1,200 \mathrm{~kg} / \mathrm{m}^{3}$ in the landfill, the average is $950 \mathrm{~kg} / \mathrm{m}^{3}$. The weight of the municipal solid waste introduced to each barrel has been calculated by the following equation (1)

Weight $=$ Density $X$ V olume ...... (1)

Where,

$\mathrm{W}=$ Weight of the MSW, $\mathrm{kg}$

$\mathrm{D}=$ Density of the real $\mathrm{MSW}, \mathrm{kg} / \mathrm{m}^{3}$

$V=$ Volume of the container, $\mathrm{m}^{3}$

From the equation the weight of each sample was calculated as $57 \mathrm{~kg}$ and was placed into the barrel without compaction.

\subsubsection{Amount of water needed to extract leachate from MSW}

The amount of water needed to extract leachate from MSW has been calculated by the annual precipitation that is taken in the Puducherry region by using the following Eq. 2.

$L=P(1-C)-E$

Where,

$\mathrm{L}=$ Depth of the leachate water, $\mathrm{mm}$

$\mathrm{P}=$ Precipitation, $\mathrm{mm}$

C = Runoff-Coefficient

$\mathrm{E}=$ Evaporation, $\mathrm{mm}$

The leachate coefficient (C) in this study was taken as 0.15 depending on the average daily precipitation in Puducherry (Indian meteorological department).

Depending on this data the quantity of water required for each container has been calculated by using the Eq. 3 
Where,

$\mathrm{W}=$ amount of the water to be added, $\mathrm{mL}$

$\mathrm{L}=$ Depth of the leachate water, $\mathrm{mm}$

$A=$ Area of the container or Cylinder, $m^{2}$.

The quantity of water was distributed within 60 days in each container. Since the average rainy days take place in Puducherry region is between 45 days -60 days (Department of Agricultural and farmer welfare). The rainfall and evaporation take place in winter season and the laboratory experiments were performed in the month of February and March as shown in Table 2.

Table 2

Rainfall and evaporation

\begin{tabular}{|lll|}
\hline Month & \multicolumn{1}{|l|}{ Precipitation $(\mathrm{mm})$} & Evaporation $(\mathrm{mm})$ \\
\hline \multicolumn{2}{|l|}{ winter seasons } \\
\hline September & 114 & 144 \\
\hline October & 229 & 118 \\
\hline November & 285 & 83 \\
\hline December & 144 & 65 \\
\hline Total & 772 & 410 \\
\hline Experimental season & \\
\hline February & 09 & 48 \\
\hline March & 08 & 85 \\
\hline Total & 17 & 133 \\
\hline
\end{tabular}

$\mathrm{L} 1=772(1-0.15)-410=246.2 \mathrm{~mm}$ in rainy season.

\subsection{MSW Leachate effect on soil using a one-dimensional technique of soil columns}

The experimental set-up comprises of seven PVC pipe soil columns. Figure 1 indicates the seven-soil columns schematic perspective. Each column was made by unification of $90 \mathrm{~mm}$ outer diameter and 80 $\mathrm{mm}$ height with an anti-corrosive coated hopper portion with a wire mesh placed between the soil-column and hopper portion. An outlet control valve was installed in the hopper portion to regulate the outlet flow, which is connected to a drain outlet ( $8 \mathrm{~mm} \mathrm{dia)}$. 
The leachate extracted from the MSW was percolated into the soil column by feeding through the feeding tank (140 mm dia $\times 450 \mathrm{~mm}$ height) fitted with the inlet control valve at the bottom and the inlet feed tube (8 $\mathrm{mm}$ diameter tube) connecting the soil column with the feed tank.

\subsubsection{Preparation of soil-column and loading conditions}

Soil samples (weighing $2.7 \mathrm{~kg}$ ) were mixed with leachate corresponding to their optimum moisture content and loaded in the seven columns of the soil. The first columns stated as OT and the remaining six columns as stated as ST. Leachate outflow samples were collected from the drain outlet at a 48-hour interval. The chemical analysis was carried out for the outlet leachate collected from the soil column marked as OT. The soil sample was gathered for soil testing at a periodic interval of every 15 days at the remaining six columns as called ST. For each of the soil columns, about $1.2 \mathrm{~L}$ of extracted leachate was packed in the feed tank.

\subsection{Analysis of geotechnical characteristics of soil}

The soil sample was collected at an interval of 15 days for soil testing. The testing parameter are Liquid limit (LL), Plastic Limit (PL), Shrinkage Limit (SL), and Grain Size Distribution by Hydrometer Analysis, Unconfined Compressive Strength (UCS), Proctor Compaction, Hydraulic Conductivity and Scanning Electron Microscopy (SEM) are conducted as per standard IS and ASTM soil testing methods.

\section{Results And Discussion}

\subsection{Characterization of extracted leachate}

The characterization of extracted leachate is shown in the Table 3 . The $\mathrm{pH}$ value of the leachate was slightly decreased from 7.22 to 6.83 at the end of 45 days and then increased at last 15 days. The decrease in $\mathrm{pH}$ value signifies that the degradation process has taken place between the municipal solid waste and the water. The $\mathrm{pH}$ value reduced as the time period increased due to the biodegradation process of the carbohydrate present in the leachate changed into fatty acids is the major impact in the decrease of $\mathrm{pH}, \mathrm{EC}$ and TDS values was increased from $5328 \mathrm{mg} / \mathrm{L}$ to $5832 \mathrm{mg} / \mathrm{L}$ at the end of 45 days and then slightly decreased at last 15 days (5). The increase in EC and TDS values shows that the presence of inorganic content in the leachate. Further addition of water a dilution process has been taken place and decreases the values. Similar explanation was stated (6), the fluctuation in EC and TDS values principally related to the concentration of inorganic matter present in the municipal solid waste leachate, further addition of water the dilution process has been taken and reduces the concentration of inorganic matter during the short experimental period of time. COD values has been increased from $2130 \mathrm{mg} / \mathrm{L}$ to $4166 \mathrm{mg} / \mathrm{L}$ and then slightly decreased. The increase of COD value signifies that the presence of organic content in the leachate. Similarly, other parameters such as $\mathrm{Ca}, \mathrm{Mg}, \mathrm{Cl}$ and Alkalinity were initially increased and then decreased. The increase of chloride is responsible for the dissolved solid present in the leachate. The results of the test show that the amount of leachate obtained is significantly greater 
than the leachate of the dumping site. Since, the concentration of fresh leachate is higher than the matured leachate.

Table 3

Characteristics of extracted leachate

\begin{tabular}{|c|c|c|c|c|}
\hline \\
\hline Parameters analyzed & 15 days & 30 days & 45 days & 60 days \\
\hline $\mathrm{pH}$ & 7.22 & 6.98 & 6.83 & 6.86 \\
\hline $\mathrm{EC}(\mu \mathrm{S} / \mathrm{cm})$ & 5328 & 5522 & 5832 & 4728 \\
\hline TDS (mg/L) & 4370 & 4750 & 5220 & 4200 \\
\hline COD (mg/L) & 2130 & 3048 & 4166 & 3500 \\
\hline Calcium (mg/L) & 454 & 550 & 474 & 355 \\
\hline Magnesium (mg/L) & 455 & 643 & 562 & 512 \\
\hline Chloride(mg/L) & 1035 & 1340 & 1558 & 1285 \\
\hline Alkalinity (mg/L) & 3480 & 4550 & 4600 & 4205 \\
\hline
\end{tabular}

The geotechnical characteristic of soil is highly contaminated due to the effect of leachate. Onedimensional soil column process is stimulated to assess the effect of leachate on the soil sample. Seven soil columns were taken and each column was filled with soil and the leachate was passed continuously through the soil by the inlet valve pipe for 105 days and every 15 days the soil sample were taken and analyzed. The long-term interaction of leachate with the soil changes the soil, the behavior and properties due the chemicals present in the leachate.

\subsubsection{Variation in Consistency limits}

The liquid limit, plastic limit and plasticity index was found to be increased for 75 days and after that to a lesser extend at last 30 days as shown in the Fig. 2. The changes in liquid limit, plastic limit and plasticity index are principally related to the chemicals in the leachate which stimulate the aggregation of particles and increase the content of clay. Hence further addition of leachate and time period alter the soil particle into dispersive and reduce the diffuse double layer thickness of soil, thus may led to decrease the consistency limit of the soil. Conversely shrinkage limit was decreased by increasing the addition of leachate. The decrease in shrinkage value mainly due to chemical present in the leachate increases the soil particle flocculation, thus resulting in higher value of shrinkage limit (7).

\subsubsection{Variation in Proctor Compaction}


The proctor compaction test has been conducted to assess the MDD and OMC changes take place in the contaminated soil. The test result shows that there is a small reduction in maximum dry density. It was changed from $1.77 \mathrm{~g} / \mathrm{cc}$ to $1.64 \mathrm{~g} / \mathrm{cc}$ and optimum moisture content was changed from 17.05-18.45\% as shown in the Fig. 3 . The reduction in maximum dry density is related to the changes in the microstructure of the soil particles.

\subsubsection{Variation in Unconfined compressive strength}

The variation in UCS is shown in the Fig. 4. The UCS was increased from $167.80 \mathrm{kPa}$ to $176.54 \mathrm{kPa}$ up to 75 days and then the value was slightly decreased at the end of 90th to 105th days. The increase in UCS is principally due to the interaction of MSW leachate into the soil changes. The soil particle aggregation to a flocculated structure and also depends upon the percentage of clay content. However, the further addition of leachate and interaction time period changes the soil particles into dispersion thus leading to the reduction in UCS of the soil (8).

\subsubsection{Variation in Hydraulic Conductivity}

The hydraulic conductivity was decreased gradually at the beginning of contamination time and then slightly increased and stabilized at the end of the experiment. The test outcome indicated that the hydraulic conductivity was changed from $8.36 \times 10^{-5} \mathrm{~cm} / \mathrm{s}$ to $1.28 \times 10^{-4} \mathrm{~cm} / \mathrm{s}$ as shown in the Fig. 5 . It noted that the reduction in hydraulic conductivity was primarily due to the bio-clogging impact of the bacteria present in the leachate. However further addition of leachate and time period collapse the bioclogging effect and changes the soil structure which affect the permeability of the soil, thus may increase the hydraulic conductivity value (9).

\subsubsection{Scanning Electron Microscope Imagery (SEM)}

A microscope experiment was used to observe modifications in the contaminated soil microstructure. The Fig. 6 represents the SEM-micrograph of the unaffected soil sample exhibit layered structure and they are uniformly arranged. After contamination the soil particle is formed by agglomeration of small grains with dispersive microstructure as shown in the Fig. 7. The dispersive structure in the soil sample is leading cause for increasing the permeability value (10).

\section{Conclusion}

A laboratory experiment was performed using a one-dimensional column set-up technique to determine the soil-pollutant interaction. The following findings are drawn on the basis of the research.

\section{Characteristics of prepared leachate from the MSW}

The test outcome indicates that the leachate level increased up to 45 days and then started to slightly decrease over the 50th to 60th day due to leachate dilution. However, the concentration of prepared leachate differs slightly from the leachate of the landfill. The $\mathrm{pH}$ value is 6.86 , that is slightly acidic and the other parameter such as EC, TDS, chloride, calcium, magnesium, alkalinity and COD exceeds the 
permissible limit of Standard leachate disposal. The elevated TDS and COD concentration exhibits the existence in the leachate of both organic and inorganic elements.

\section{Soil Characteristics}

The soil sample long term effect of MSW leachate increases the soils liquid limit, plastic limit, and plasticity. Conversely, after contamination, it decreases the shrinking limit value. The unconfined compressive strength increased up to 75 days from $167.80 \mathrm{kPa}$ to $176.54 \mathrm{kPa}$ and reduced over the 95th to 105th day. Conversely, in the original phase, hydraulic conductivity decreased and gradually increased in the final phase. These changes in soil characteristics are primarily due to modifications in soil particle microstructure and the effect of leachate chemicals. The chemicals present in the soil particle leachate into a dispersive structure with an efficient pore space that reduces soil strength and increases the significance of permeability.

\section{Declarations}

\section{Availability of data and materials}

All the data generated or analyzed during this study are fully available in the supplementary materials.

\section{Acknowledgements}

Authors thank the department of civil engineering for providing the laboratory facilities to conduct the experiments.

\section{Funding}

No specific funding has been received for this study from any particular agency.

\section{Author information}

Affiliations

\section{Pondicherry Engineering College, Puducherry, 605014, India}

\section{Dr. V. Murugaiyan, Dr.R.Rajapriya}

\section{Contributions}

RR and VM is the main author who wrote the ideas and interpreted the results of the manuscript and responsible for the data collection, analysis and presentation. Both authors read and approved the final manuscript. Both the authors read and approved the final manuscript. 
Correspondence to Dr.R.Rajapriya

\section{Ethics declarations}

Competing interests

The authors declare they have no competing interests.

\section{References}

1. Buenrostro O, Bocco G. Solid waste management in municipalities in Mexico: Goals and perspectives. Resour Conserv Recycl. 2003;39(3):251-63.

2. Pokhrel D, Viraraghavan T. Municipal solid waste management in Nepal: Practices and challenges. Waste Manag. 2005 Dec 31;25(5):555-62.

3. Anilkumar, Anju, Dipu Sukumaran SGTV. Effect of Municipal Solid Waste Leachate on Ground Water Quality of Thiruvananthapuram District, Kerala, India. Ekol Terap dan IImu Lingkung [Internet]. 2015;3(5):151-7.

4. Hossain ML, Das SR, Hossain MK. Impact of landfill leachate on surface and ground water quality. J Environ Sci Technol. 2014;7(6):337-46.

5. Aish A, Abushbak T, El-nakhala M. Investigation of The Fate Of MSW Leachate In Different Soil Types Using Soil Column Method. J Environ Earth Sci. 2014;4(4):72-80.

6. Ramia Bassam Rida Tuffaha. Impacts of solid waste leachate on soil and its simulation to groundwater at Nablus Areale. 2006.

7. Goswami D. Atterberg's Limit and Shear Strength Haracterestics of Leachate Contaminated Lateritic Soil. Paripex Indian J Res. 2013;113-6.

8. Resmi G, G Thampi S, Chandrakaran S. Impact of Lead Contamination on the Engineering Properties of Clayey Soil. J Geol Soc India. 2011;77:42-6.

9. Yantrapalli SK, Krishna P H, Srinivas S. A Study On Influence Of Real Municipal Solid Waste Leachate On Properties Of Soils In Warangal, India. J Geosci Eng Environ Technol. 2018;3(1):25.

10. Sivapullaiah P.V. Effects of soil pollution on geotechnical behaviour of soils. In: Effects of soil pollution on geotechnical behaviour of soils. 2009. p. 933-40.

\section{Figures}




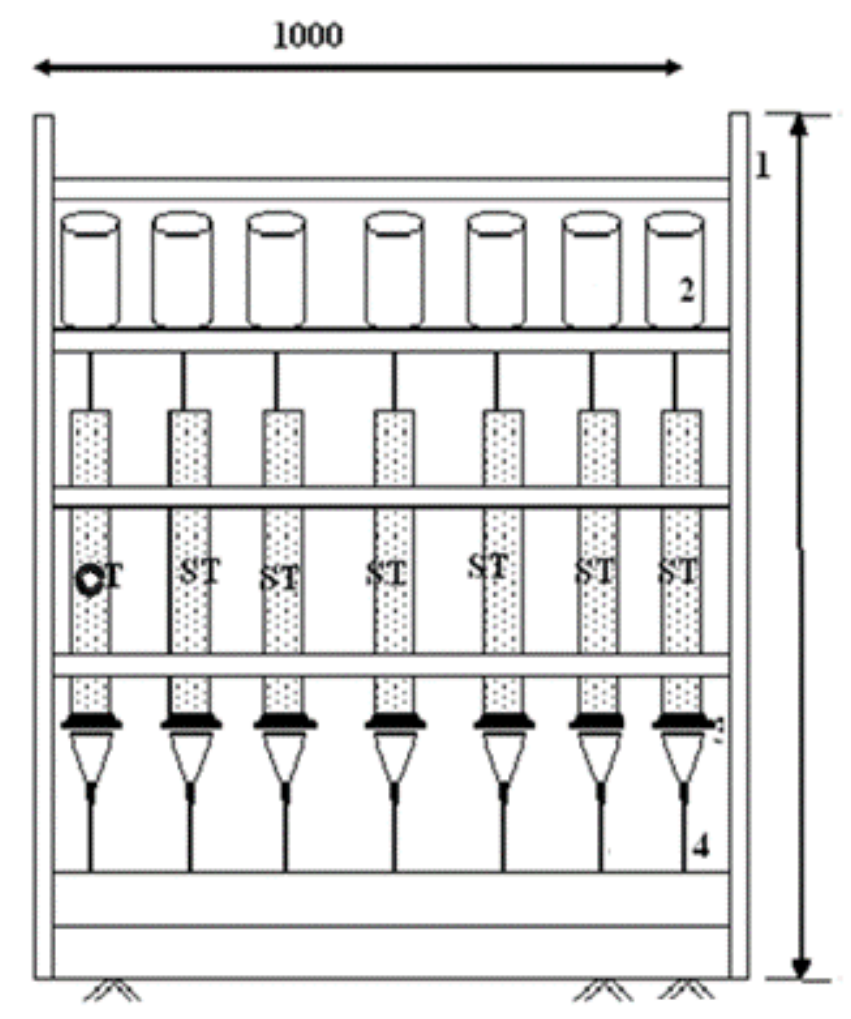

1-Supporting Frame

2- Feeding Tank

3. Wire mesh

4. Outlet Drain

5. OT, ST- Column

for outflow test and

soil test

All dimensions are in

$\mathrm{mm}$

\section{Figure 1}

Schematic Diagram for Experiment set-up

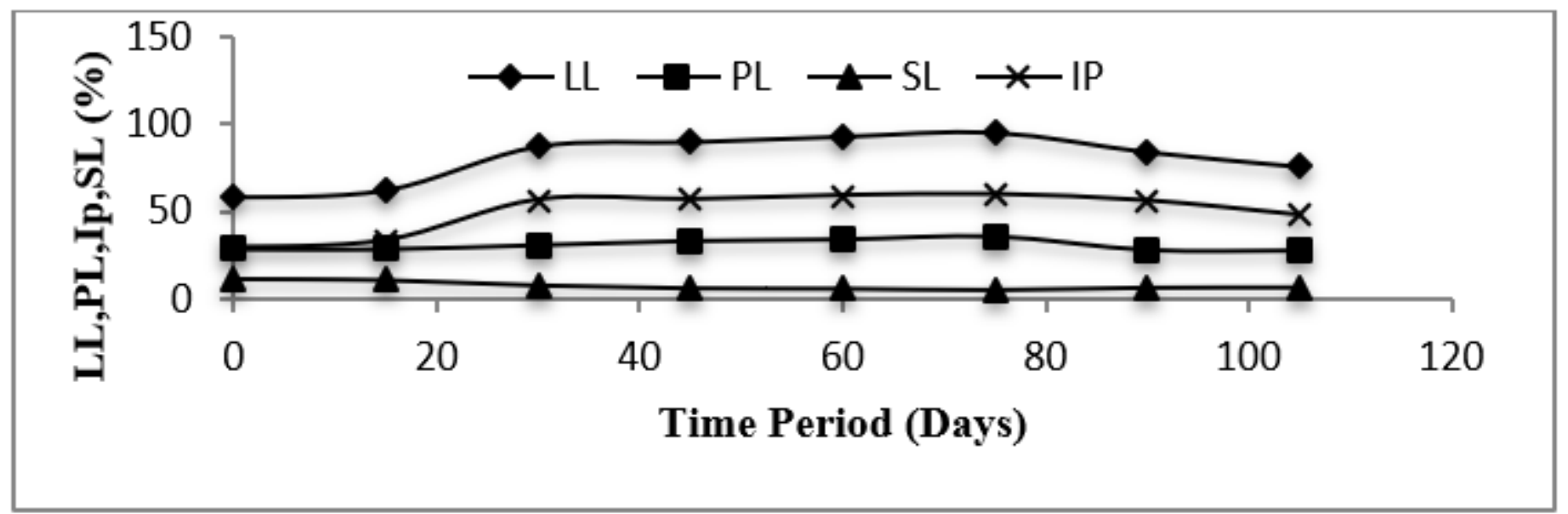

Figure 2

Variation in Consistency limits 


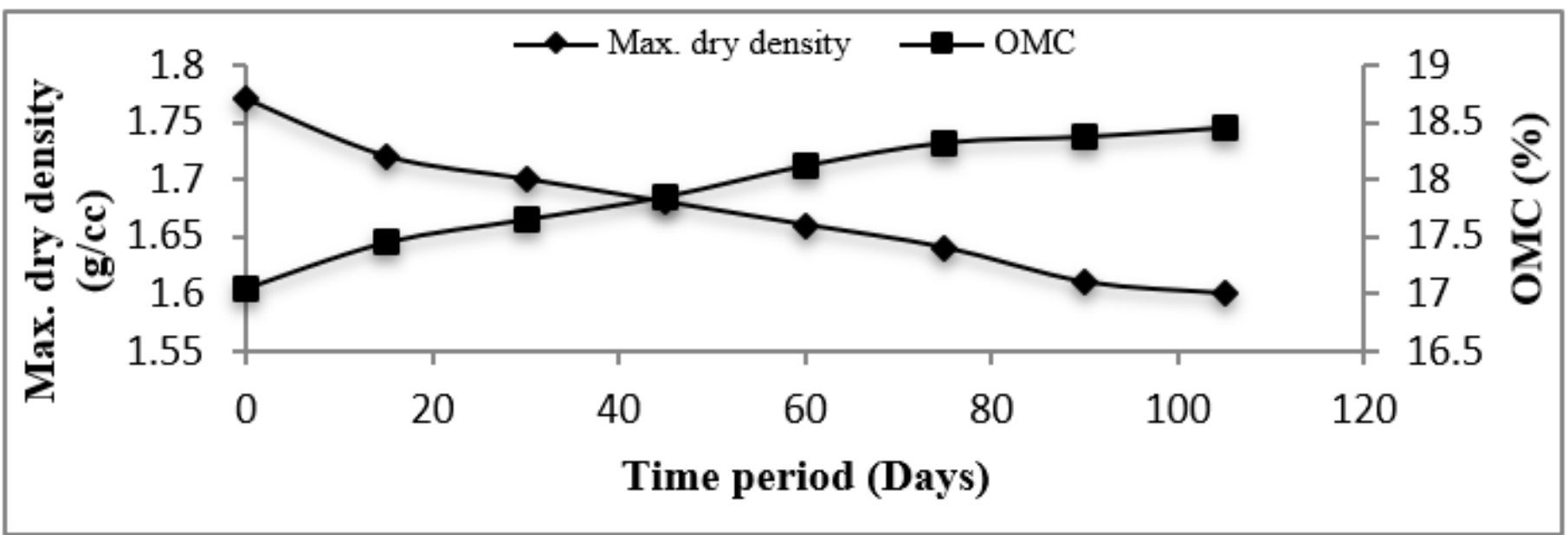

Figure 3

Variation in Proctor Compaction

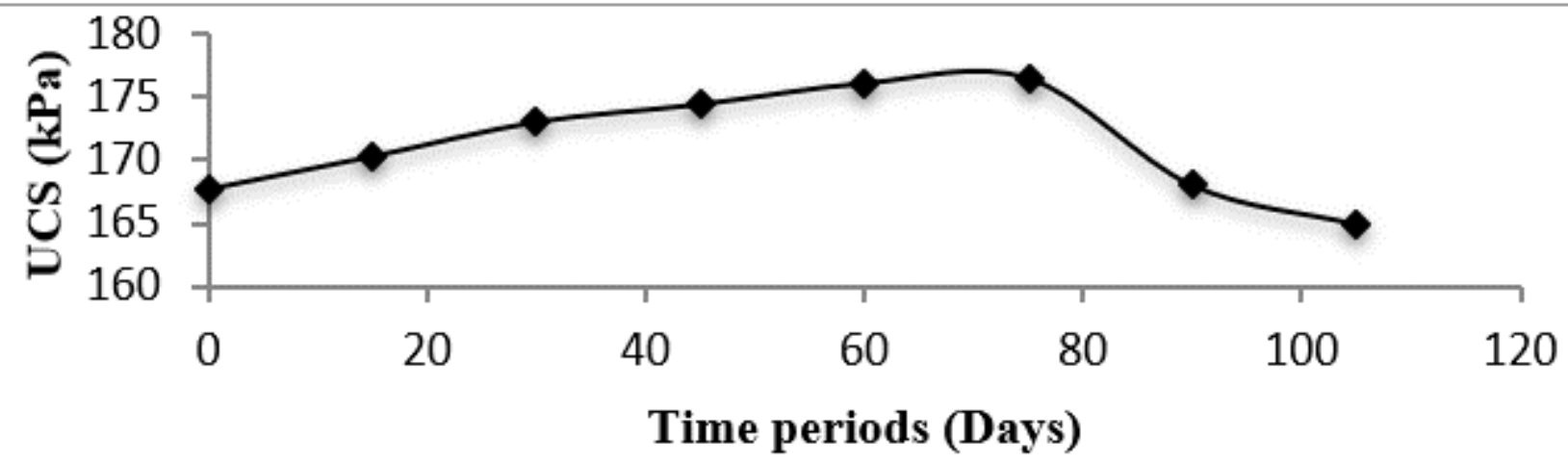

Figure 4

Variation in Unconfined Compressive Strength

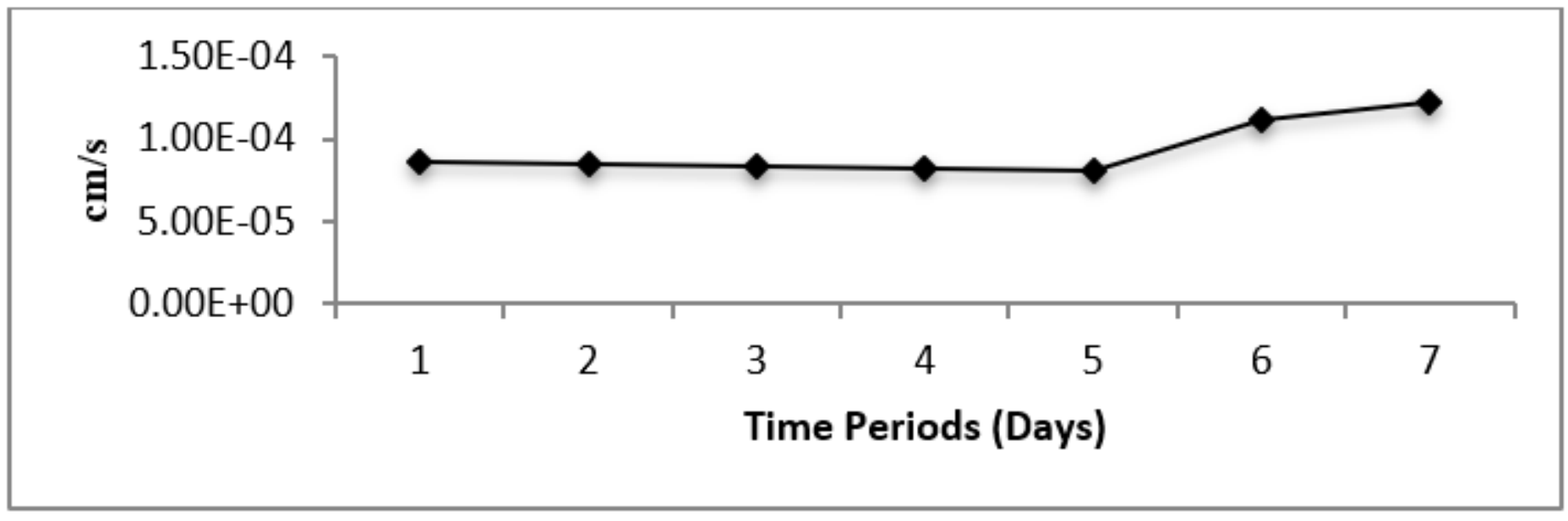

Figure 5 
Variation in Hydraulic Conductivity

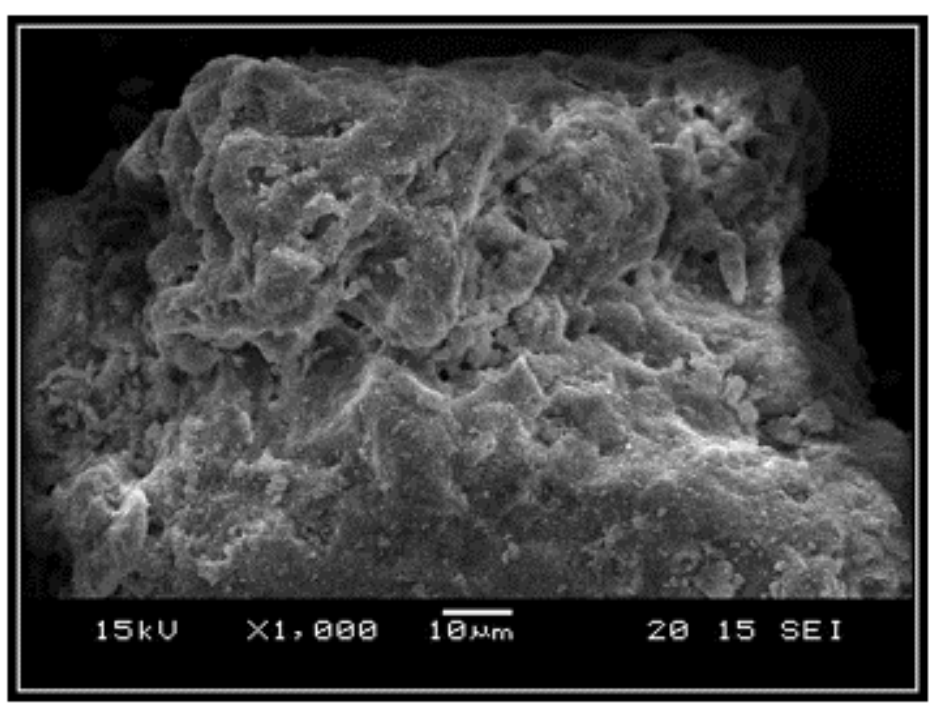

\section{Figure 6}

Scanning uncontaminated soil sample electron microscopy

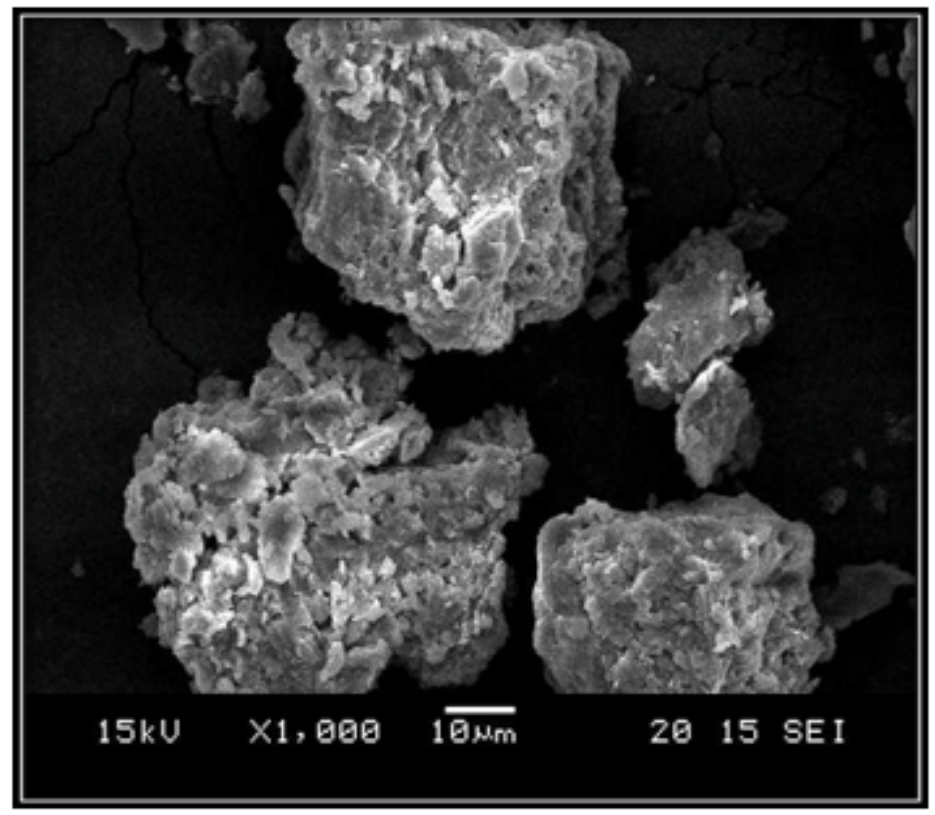

Figure 7

Scanning contaminated soil sample electron microscopy 